\section{CHYTROST BEZ POROZUMĚNÍ: HYPOTÉZA KULTURNÍ INTELIGENCE A JEJÍ LIMITY}

\begin{abstract}
Abstrakt: Člověk je mimořádně přizpi̊sobivým, a proto úspěšným živočišným druhem. Existuje mnoho spekulativních odpovědí na otázku, proč tomu tak je. Jednu $z$ nich predstavuje hypotéza kulturní inteligence, která uvažuje o schopnosti kulturního učení jako o klíčiklidskému úspěchu. Cílem této práceje představit hypotézu kulturní inteligence jako podnètnou alternativu $k$ etablovanějším prístupưm $v$ otázkách po pưvodu lidské inteligence $v$ čele s hypotézou obecné a improvizační inteligence. Jejich vzájemná komparace ukazuje, že hypotéza kulturní inteligence musí př popisu kulturní transmise nutně pracovat sflexibilními strategiemi sociálniho učení, čímž ztrácí ćást své explanační síly. Nicméně to nemusí být ještě duvod k odmítnutí jejího zdravého jádra, protože existuje možnost, jak zkombinovat flexibilitu lidského uvažování s,hloupým" procesem kulturní selekce, kterou nabizí koncepce metakognitivnich strategii sociálního učení kognitivní psycholožky Cecilie Heyesové.
\end{abstract}

Klíčová slova: kultura; intelligence; evoluce; sociální učení; inovace; kolektivní mozek; Cecilia Heyes

\section{PETR MATĚJÍČEK}

Katedra filozofie a společenských věd Univerzita Hradec Králové

\section{Smartness without Insight: Cultural Intelligence Hypothesis and Its Limits}

Abstract: Humans are remarkably adaptable, and therefore a successful species. There are many speculative answers to the question of why this is so. One of them represents the cultural intelligence hypothesis, which considers cultural learning skills as the key to human success. This work aims to present the hypothesis of cultural intelligence as a viable alternative to more conventional approaches within the debate about the origin of human intelligence, such as the hypothesis of general and improvisational intelligence. Their mutual comparison shows that cultural intelligence hypothesis must necessarily work with flexible social learning strategies to describe cultural transmission, thus losing part of its explanatory power. As the theory of metacognitive strategies of social learning by cognitive psychologist Cecilia Heyes shows, there is a way to combine the flexibility of $\mathrm{hu}$ man reasoning with the "stupid" process of cultural selection.

Keywords: culture; intelligence; evolution; social learning; innovation; collective brain; Cecilia Heyes

nám. Svobody 331, 50003 Hradec Králové email / petr.matejicek.1@uhk.cz

(c) (1) Toto dílo podléhá licenci Creative Commons Attribution 4.0 International. 


\section{1. Úvod}

Výzkum kulturní evoluce se stal jedním z nejplodnějších teoretických přístupů při výzkumu lidského chování, který začíná významně překreslovat metodologické a konceptuální rozhraní jednotlivých sociálních a humanitních disciplín. Jeden $\mathrm{z}$ nejvlivnějších přístupů této oblasti př̀edstavuje hypotéza kulturní inteligence, která označuje za hlavní linii antropologické diference specificky lidskou schopnost kulturního učení. Lidská výjimečnost podle ní nespočívá primárně $\mathrm{v}$ individuálních kognitivních kapacitách umožňujících řešit většinu adaptivních problémů za pomoci kognitivních instinktů ${ }^{1}$ a individuálního učení, ale ve schopnosti obratně využívat výhod naakumulovaných adaptivních informací často bez znalosti kauzálního mechanismu, který je činí efektivním nástrojem $\mathrm{k}$ dosahování cílů našeho jednání. Cílem této práce je představit v širších souvislostech hypotézu kulturní inteligence, která značí radikální odklon od tradičních teorií obecné inteligence, jež mají sklon vykreslovat lidskou mysl jako izolovaný psychologický nástroj s primárně epistemickou funkcí: jeho hlavní účel spočívá v poskytování co nejtransparentnějších reprezentací o vnějším fyzickém a sociálním světě. Tato tendence vede na úrovni studia kultury $\mathrm{k}$ hledání inteligentního designu i v př́padech, $\mathrm{v}$ nichž chybí. ${ }^{2}$

V první části tohoto článku představím detailněji teoretické předpoklady hypotézy kulturní inteligence. Zaměřím se na pojem sociálního učení a jeho specifickou podobu u člověka ve formě tzv. kulturního učení. Zároveň budu věnovat pozornost dynamice sociálního učení a vlivu strategií soci-

Vznik textu podpořil Referát vědy a zahraničních styků Filozofické fakulty Univerzity Hradec Králové v rámci Specifického výzkumu za rok 2017.

${ }^{1}$ Kognitivní instinkt představuje jeden ze základních pojmů evoluční psychologie, který vyjadřuje předpoklad, že podoba lidské mysli a její mechanismy jsou do značné míry formovány procesem přirozeného výběru. Kognitivní instinkty označují sadu genetických předpokladů, které řídí rozvoj specificky lidských forem kognitivních mechanismů (typicky jazyk, čtení mysli, sociální učení). Viz Cecilia Heyes, „Cognitive Gadgets: The Cultural Evolution of Thinking," Cognitive Gadgets: The Cultural Evolution of Thinking. (Cambridge, MA: Harvard University Press, 2018), 7-24.

2 Michael Muthukrishna and Joseph Henrich, "Innovation in the Collective Brain," Philosophical Transactions of the Royal Society B: Biological Sciences 371, no. 1690 (2016): 1-14. 
álního učení na jeho adaptivní hodnotu. ${ }^{3} \mathrm{~V}$ druhé části práce představím možná nejambicióznější rozvedení hypotézy kulturní inteligence v pracích Michaela Muthukrihny a Josepha Henricha. Jejich vlastní hypotéza kolektivního mozku si bere za cíl poskytnout prostřednictvím série formálních matematických modelů kulturní transmise a antropologických dat alternativní vysvětlení původu lidského inovačního potenciálu, $v$ němž hrají ústřední úlohu kognitivní zkreslení a „slepý“ proces selekce kulturních variant. ${ }^{4}$ Budu tvrdit, že kognitivní model hypotézy kolektivního mozku je těžko udržitelný a uvedu některé alternativní teorie procesu sociálního učení a procesu rozhodování. Ty ukazují, že lidé jsou při volbě sociálního a individuálního učení mnohem flexibilnější, strategičtější a vysoce citliví na aktuální situační kontext. V poslední části představím teorii metakognitivních strategie sociálního učení Cecilie Heyesová, která ukazuje cestu, jak by bylo možné skloubit flexibilitu lidského rozhodování s procesem kulturní selekce.

\section{Od obecné ke kulturní inteligenci}

$\mathrm{Na}$ otázku po specifických schopnostech, jež lidem umožnily se pružně přizpůsobovat nejextrémnějším klimatickým podmínkám a stát se dominantním živočišným druhem, neexistuje konsenzuální odpověd a je dodnes předmětem neustálých teoretických sporů, které lemují debatu o antropologické diferenci. Právě behaviorální flexibilita, pomocí níž jsou jednotlivé organismy schopny se účelně adaptovat na proměny vnějšího prostředí, je často spojována $s$ inteligencí. To samozřejmě předpokládá množinu pro-

\footnotetext{
${ }^{3}$ Pojem adaptivní hodnoty popisuje $\mathrm{v}$ tradici populační genetiky užitečnost zkoumaného dědičného znaku pro přežití organismu v určitém prostředí. Jedná se o veličinu, která vyjadřuje relativní reprodukční schopnost určitého genotypu, tj. míru jeho zastoupení v genetickém fondu další generace, které je podmíněno reprodukčním úspěchem nositelů daného genotypu. Viz Bruce Wallace, „The Estimation of Adaptive Values of Experimental Populations, “Evolution 6, no. 3 (1952): 333-41.

${ }^{4} \mathrm{~V}$ tradici teorie kulturní evoluce je pojem kulturní varianty používán jako přibližný ekvivalent genů. Tento př́ístup však nutně naráží na své limity, protože kultura je svojí komplexní povahou těžko převoditelná na systém diskrétních jednotek. Podle Boyda a Richersona je koncept kulturní varianty použitelný $\mathrm{v}$ kontextu kulturní evoluce $\mathrm{v}$ případě, že jsou splněny dva základní předpoklady: 1) existence kulturních charakteristik, které mohou být př̀nášeny od jednoho jedince $\mathrm{k}$ druhému; 2) existence různých variant těchto charakteristik mezi jednotlivci a populacemi. Peter J. Richerson a Robert Boyd, V genech není všechno, aneb, Jak kultura zmènila evoluci člověka (Praha: Academia, 2012), 76-98.
} 
ximátních mentálních mechanismů, které jsou zodpovědné za dosahování adaptivního chování jednotlivých organismů. ${ }^{5}$

Jestliže bychom vymezili inteligenci takto liberálně - tj. jako sadu schopností, která zajištuje adaptibilitu organismu prostřednictvím účelného přizpůsobování chování změnám prostředí (ve smyslu úspěšného řešení problémů) - je nasnadě, že klič k lidského úspěchu úzce souvisí se specificky lidským typem inteligence. V evropské myšlenkové tradici byly za hlavní dělicí linii mezi člověkem a ostatními živočišnými druhy dlouho považovány vlastnosti lidského myšlení, které je možné označit za rozumové: v podobě pojmového a abstraktního myšlení, logického usuzování nebo jazyka. Tyto výlučně lidské atributy obecné inteligence měly člověka pomyslně odpoutat od závislosti na instinktivním zpracovávání informací z okolního prostředí a umožnit mu do velké míry dekontextualizovat vlastní modely myšlení. Prizmatem hypotézy obecné inteligence jsou lidé v komparaci s ostatními živočišnými druhy schopni se mnohem dynamičtěji přizpůsobovat různorodým ekologickým podmínkám a řešit nové existenční výzvy prostřednictvím doménově-obecných kognitivních operací (větši kapacity dlouhodobé a operační paměti, rychlejšího percepčního zpracovávání, rozvinutých způsobů usuzování). ${ }^{6}$

Výzkumy na poli kognitivní psychologie, primatologie a kognitivní etologie $\mathrm{v}$ posledních dekádách výrazně otřásly základními předpoklady hypotézy obecné inteligence Odhalují totiž velkou míru předsudečnosti vůči kognitivní úrovni ostatních živočišných druhů, se kterou teorie obecné inteligence pracuje. Ukazuje se, že zejména šimpanzi jsou vybaveni netriviálními formami usuzování, metakognice, morální psychologie, pokročilých způsobů sociálního učení a zárodky kulturních tradic. ${ }^{7}$ Vlivem vzrůstajícího

\footnotetext{
${ }^{5}$ Jak upozorňuje Richard Byrne, u pojmů inteligence a racionality nepanuje v psychologické literatuře obecný konsensus ohledně jejich významu. Naopak převládá nemalá míra variability při jejich definování u jednotlivých autorů, kteří často kladou důraz na rozdílné aspekty, jež jsou tradičně s těmito pojmy asociované (abstraktní myšlení, schopnost usuzování, jazykové schopnosti atd.). Byrne se snaží najít určitý společný bod, který by tyto př́ístupy integroval a nabídnul sjednocující vymezení inteligence. To spatřuje ve schopnosti plasticky a účelně reagovat na změny v okolním prostředí. Richard Byrne, The Thinking Ape: Evolutionary Origins of Intelligence (Oxford: Oxford University Press, 1995), 31-43.

${ }^{6}$ Hypotézu obecné inteligence lze ilustrovat na př́íkladu konceptu produktivního myšlení Maxe Wetheimera: Max Wertheimer, Productive Thinking (Westport, CT: Greenwood Press, 1978); Wolfgang Köhler, The Mentality of Apes (New York: Liveright, 1976).

${ }^{7}$ Robustní schopnosti abstraktního myšlení a uvažování dokumentují výzkumy shrnuje ve své knize Natural History of Human Thinking Michael Tomasello. Michael Tomasello, A Natural History of Human Thinking (Cambridge, MA: Harvard University Press, 2014), 15-26.
} 
množství poznatků o kognitivních zkresleních a systematických chybách lidského rozhodování - odhalující značný rozpor mezi logickými principy a reálnou funkcí lidské kognice - se zvyšuje rovněž tlak na revizi obrazu člověka jako vesměs racionálního aktéra. ${ }^{8}$

Konkurenční výklad zdroje flexibility lidského myšlení představuje hypotéza adaptivní inteligence, která akcentuje primární vliv selekčních tlaků vnějšího prostředí př̀i utváření lidské mysli. Lidská kognice je podle této premisy vybavena celou sadou rozličných doménově-specifických modulů, jež se vyvinuly ve vztahu k různorodým výzvám v kontextu fyzického a sociálního prostředí, ve kterém se člověk pohyboval po většinu své evoluční historie (tj. v prostředí evoluční adaptovanosti). Základní myšlenka adaptivních př́stupů tkví v předpokladu, že specifické kognitivní procesy (zpracování jazyka, teorie mysli atd.) jsou efektivněji prováděny specializovanými kognitivními centry nežli jedním univerzálním „one fits all“ mechanismem. $\mathrm{K}$ vyřešení rébusu antropologické diference a pochopení funkce lidské mysli je podle proponentů hypotézy adaptivní inteligence potřeba zrekonstruovat podrobně naši evoluční historii a identifikovat jak na jedné straně nejdůležitější selekční faktory vnějšího prostředí, tak i adekvátní sadu kognitivních mechanismů, které vznikly jako biologické adaptace v reakci na dané existenční výzvy. ${ }^{9}$ Největší výzvu pro teorie spojené s hypotézou adaptivní inteligence představuje vysvětlení kognitivní flexibility. Pokud by opravdu kognice sestávala $\mathrm{z}$ množiny specializovaných kognitivních modulů, které byly selektovány v průběhu evoluce ke zpracovávání úzce vymezených typů informačních zdrojů, vyvstává zákonitě otázka, jestli je takovýto obraz funkčního uspořádání kognitivního aparátu možné aplikovat na popis dynamického chování člověka.

Ukázkou př́stupu, který se snaží navzájem skloubit flexibilitu lidského myšlení s ideou masivní modularity, je teorie improvizační inteligence, ${ }^{10}$

\footnotetext{
${ }^{8}$ Příklady systematických chyb lidské kognice a jejich výzkum v rámci kognitivních věd shrnují ve své popularizační knize např. Richard Thaler a Cass Sunstein: Richard H. Thaler a Cass R. Sunstein, Nudge (Štouch): Jak postrčit lidi k lepšímu rozhodování o zdraví, majetku a štěstí (Zlín: Kniha Zlín, 2010).

${ }^{9}$ Hlavní předpoklady hypotézy adaptivní inteligence lze ilustrovat na prŕstupu zástupců evoluční psychologie v čele s Cosmidesovou, Toobym a Barkowem: Jerome H. Barkow, Leda Cosmides, and John Tooby, The Adapted Mind: Evolutionary Psychology and the Generation of Culture (New York: Oxford University Press, 1992), 8-14.

${ }^{10}$ Teorii improvizační inteligence detailněji představují Cosmidesová a Tooby v článku „Unraveling the Enigma of Human Intelligence“: John Tooby and Leda Cosmides, „Unraveling the Enigma of Human Intelligence: Evolutionary Psychology and the Multimodular Mind,“ The Evolution of Intelligence, no. 67 (2001), 145-98.
} 
podle níž je lidská mysl vybavena dvěma komplementárními typy inteligentního jednání. Prvním z nich je tzv. jednoúčelová inteligence (dedicated intelligence), kterou člověk sdílí s ostatními živočišnými druhy. Ta sestává $\mathrm{z}$ vysoce specializovaných výpočetních modulů orientujících se při zpracovávání dat pravidelnostmi, které byly typické pro prostředí evoluční adaptovanosti jednotlivých druhů. Druhým typ představuje tzv. improvizační inteligence (improvisational intelligence), která je mnohem variabilnější ve svém informačním nastavení a zaměřuje se $\mathrm{v}$ porovnání se systémem jednoúčelové inteligence výhradně na lokální, přechodné a $\mathrm{z}$ pohledu evolučního vývoje náhodné informační zdroje. A je to právě improvizační inteligence, která má podle Toobyho a Cosmidesové klíčový význam $\mathrm{k}$ pochopení lidské výjimečnosti: umožňuje člověku reagovat pohotověji na nové existenční výzvy prostřednictvím manipulací mentálních modelů vnějšího světa $\mathrm{v}$ mentálním prostředí tzv. kognitivní niky. ${ }^{11}$ Lidé dokážou prostřednictvím improvizační inteligence využívat nejen samotné fyzické prostředí k získání adaptivních informací, ale mohou pomocí inferenčních postupů a intuitivních pojmových schémat lidové fyziky, lidové biologie či lidové psychologie vyvozovat nové informace $\mathrm{z}$ interních mentálních reprezentací. Funkčnost samotných produktů improvizační inteligence ve formě nástrojů, zbraní, léků atd. může být následně testována jak v abstraktním prostoru kognitivní niky, tak i fyzického světa. Lidé tudíž nejsou odkázání pouze na filtrovací efekt přirozeného výběru, ale podobnou úlohu sehrává lidská schopnost reflexe úspešnosti vlastních rozhodnutí v minulosti a korekce jejich mentálních modelů. Teorie improvizační inteligence vykresluje lidskou mysl jako pomyslnou mentální laboratoř a trenažer zároveň. Tím ale zároveň otevírá prostor nebezpečí kombinatorické exploze. Přestože její zastánci zdůrazňují úzkou provázanost improvizačního systému s jednoúčelovou inteligencí, zůstává stále otázkou, jak je možné skloubit improvizační procesy s ideou masivní modularity. Navíc historická a antropologická literatura dokumentuje, jak bezmocný je člověk spoléhající se pouze na vlastní

${ }^{11}$ Termín kognitivní niky poprvé použili John Tooby a Irven DeVore k popisu specificky lidského způsobu využívání ekosystémů prostřednictvím pokročilých forem usuzování a spolupráce. Lidé jsou podle nich schopni využívat zdroje a opanovat určité prostředí mentální simulací příčinách vztahů ve svém okolí a tomu přizpůsobovat své chování. John Tooby and Irven DeVore, „The Reconstruction of Homind Behavioral Evolution through Strategic Modeling," in The Evolution of Human Behavior: Primate Models, ed. W. G. Kinzey (New York: State University of New York Press, 1987), 210. 
kognitivní instinkty a obecné formy usuzování při individuální adaptaci na nové prostředí. ${ }^{12}$

Hypotéza kulturní inteligence nabízí jiný výklad flexibilní adaptace člověka na měnící se charakter sociálního a fyzického prostředí. Ústřední místo $\mathrm{v}$ ní zaujímá specificky lidský fenomén kulturního učení a s ním spojený proces kumulativní kulturní evoluce, prostřednictvím něhož se v lidských skupinách formuje $\mathrm{v}$ průběhu času množina předávaných kulturních variant (normy, chování, technologie, přesvědčení atd.). Ty slouží jako „uložiště“, v němž se postupně hromadí úspěšné inovace a modifikace, které lidem umožňují se přizpůsobovat nejrůznějším ekologickým a sociálním podmínkám mnohem rychleji a účelněji než geneticky asimilované kognitivní instinkty a individuální učení. Ustálení mechanismů zajištujících stabilitu a kumulaci kulturních inovací vede ke vzniku stabilních kulturních tradic, které postupně transformovaly fyzické a sociální prostředí ve specificky lidské kulturní prostředí. A tato kulturní nika pak podle proponentů hypotézy kulturní inteligence začala vytvářet dostatečně silný selekční tlak, který mimo jiné formoval podobu lidské kognice.

Jedním $\mathrm{z}$ takových prŕkladi̊ je vliv normativního prostředí lidských společností na lidský mozek. Koordinace sociálního života v lidských skupinách je totiž neoddělitelně spjata s rolí sociálních norem. At’ už v implicitní podobě pravidel určujících vhodné chování ve výtahu (pozdrav, vyhýbání se očnímu kontaktu) nebo ve formě explicitních právních předpisů, normy jsou hluboko vtěleny do přediv sociálních vztahů v lidských společnostech. Děti si osvojují normativní dimenzi sociální reality s obdivuhodnou lehkostí. Od útlého věku dokážou vyvozovat pravidla specifická pro okolní sociální prostředí pouhým sledováním chování druhých v různých sociálních situacích. Co je však důležitější, tato pravidla navíc spontánně převádí na normy, tj. zaujímají vůči nim normativní očekávání a vyžadují od ostatních jejich dodržování. ${ }^{13}$ Výzkumy z oblasti neurověd implikují, že dodržování, a naopak trestání transgrese norem je v lidském mozku navázáno na oblasti neurálního centra odměn. Podle Chudeka a Henricha se lidé stali v průběhu

\footnotetext{
${ }^{12}$ Joseph Henrich, The Secret of Our Success: How Culture Is Driving Human Evolution, Domesticating Our Species, and Making Us Smarter (Princeton, NJ: Princeton University Press, 2016), 22-34.

${ }^{13}$ Marco F. H. Schmidt and Michael Tomasello, „Young Children Enforce Social Norms,“ Current Directions in Psychological Science 21, no. 4 (2012): 232-36.
} 
evoluce normativní tvory právě v reakci na zvyšující se význam mezilidské spolupráce a na ní navázané sociální normy. ${ }^{14}$

Hypotéza kulturní inteligence pracuje v otázce antropologické diference $s$ alternativním zdrojem lidské inteligence v podobě transmise a kumulace kulturních informací procesem kulturního učení. Na rozdíl od hlavního proudu evoluční psychologie, hypotéza kulturní inteligence nehledá hlavní zdroj lidské „chytrosti“ v oblasti individuální kognice, ale ve více méně "slepém“ procesu šíření adaptivních informací a jejich vzájemné interakci. Takto vykreslený obraz lidské přirozenosti přisuzuje individuální inteligenci podřadnou roli: kultura - uložená v „kolektivním mozku“ sociálních skupin - je chytř̌ejší než jakýkoliv solitérní jedinec.“

\section{Strategie sociálního učení jako klíč ke kulturní inteligenci}

Hypotéza kulturní inteligence pracuje se třemi premisami týkající se výhod sociálního učení: ${ }^{15}$ 1) sociální učení představuje časově a kognitivně nenáročnou cestu, jak si osvojit potenciálně adaptivní informace ze svého sociálního prostř̌edí; 2) sociální učení výrazně snižuje riziko věnování pozornosti irelevantním informačním zdrojům; 3) přístup $\mathrm{k}$ souboru kulturních variant, které se po generace postupně kumulovaly a inovovaly. ${ }^{16}$

Jak upozornil Alan Rogers, ${ }^{17}$ nekritický typ sociálního učení, který detailněji nerozlišuje zdroj či obsah imitovaných informací, je z dlouhodobého hlediska neudržitelný. Adaptivní hodnota sociálního učení je totiž navázána na frekvenci imitátorů a inovátorů $\mathrm{v}$ populaci. Jedinci spoléhající výhradně na sociální učení by $\mathrm{v}$ prostředí, jež podléhá neustálému vývoji, imitovali po čase kulturní varianty, které jsou již zastaralé. Aby bylo sociální učení dlouhodobě udržitelnou evoluční strategií, musí obsahovat jemnější mechaniku, která by dokázala odhadovat pravděpodobnost akvizice adaptivních

${ }^{14}$ Maciej Chudek and Joseph Henrich, „Culture-Gene Coevolution, Norm-Psychology and the Emergence of Human Prosociality," Trends in Cognitive Sciences 15, no. 5 (2011): 218-26.

${ }_{15}$ Mechanismus sociálního učení je možné $\mathrm{v}$ nejobecnější podobě definovat jako proces získávání informací z prostředí, jež je prř́mo nebo neprrímo ovlivněno jednáním ostatních sociálních aktérů. Viz William Hoppitt and Kevin Laland, Social Learning: An Introduction to Mechanisms, Methods, and Models (Princeton, NJ: Princeton University Press, 2013), 3-5.

${ }^{16}$ Carel P. van Schaik and Judith M. Burkart, „Social Learning and Evolution: The Cultural Intelligence Hypothesis, "Philosophical Transactions of the Royal Society B: Biological Sciences 366, no. 1567 (2011): 1112-13.

17 Alan R. Rogers, „Does Biology Constrain Culture,“ American Anthropologist 90, no. 4 (1988): 819-31. 
informací na základě selekce relevantních sociálních zdrojů a výběru mezi sociálním a asociálním učením.

Proto Boyd a Richerson ${ }^{18}$ rozšiřují koncept sociální učení o jednoduché heuristiky, které selektivně vybírají imitované modely podle jejich prestiže (prestige bias) nebo četnosti imitovaného jednání v populaci (conformist bias). Kevin Laland ${ }^{19}$ tyto jednoduché heuristiky nazývá strategiemi sociálního učení a rozlišuje čtyři základní druhy: 1) náhodné - zdroj sociálního učení a obsah kulturních variant je vybírán náhodně; 2) kontextuální - zdroj sociálního učení je identifikován pomocí kontextuálních faktorů (napr. frekvence kulturních variant $\mathrm{v}$ populaci), vlastního stavu/situace (napřr. strategie „kopíruj, pokud si nejsi jistý“) a chování určitého preferovaného modelu (např. zkreslení prestiže, věku, známosti); 3) obsahové - kulturní varianty jsou vybírány na základě jejich strukturálních vlastností (např̀ kopírování lehce identifikovatelných a zapamatovatelných kulturních variant); 4) strategie řízené variace - individuální učení (např. metoda pokus-omyl).

Přes různé formy sociálního učení, které jsou dokumentovány u mnoha živočišných druhů, zastánci hypotézy kulturní inteligence tvrdí, že v porovnání s lidskými formami sociálního učení mezi nimi existují propastné rozdíly. Pouze u člověka totiž nacházíme natolik sofistikovaný mechanismus kulturní transmise, který zajištuje dlouhodobou kumulaci kulturních variant napříč generacemi. Před hypotézou kulturní inteligence však vyvstává otázka, co je příčinou tohoto určujícího rozdílu a jaké procesy jsou za něj př́ípadně zodpovědné.

Základním předpokladem kumulativního charakteru kultury je podle proponentů hypotézy kulturní inteligence prresná transmise kulturních variant, které je možné dále inovovat. Tomasello a Call ${ }^{20}$ tvrdí, že lidé jsou rozenými imitátory. U člověka se totiž podle nich objevuje tendence věrně napodobovat jednotlivé sekvence chování imitovaného subjektu i v takových prŕpadech, kdy mohou být některé imitované úkony $\mathrm{z}$ instrumentálního hlediska spíše redundantní. Naopak u šimpanzů v analogických situacích kladen větší důraz na samotné výsledky pozorovaného chování, tj. spoléhají

\footnotetext{
18 Robert Boyd and Peter J. Richerson, Culture and the Evolutionary Process (Chicago: University of Chicago Press, 1985), 280-94.

${ }^{19}$ Micael Ehn and Kevin Laland, „Adaptive Strategies for Cumulative Cultural Learning,“ Journal of Theoretical Biology 301 (2012): 103-11.

${ }^{20}$ Michael Tomasello and Josep Call, Primate Cognition (Oxford: Oxford University Press, 1997), 273-310.
} 
výhradně na proces emulace. ${ }^{21}$ Ačkoliv může v některých specifických případech vést emulace $\mathrm{k}$ lepším výsledkům, důraz na přesnou imitaci chování ostatních jedinců je naprosto zásadním předpokladem pro přenos kultury.

Další specifický rys lidského sociálního učení, který výrazně přispívá $\mathrm{k}$ udržení přesnosti kulturních variant, reprezentuje fenomén výuky. Korektivní chování při výuce ze strany zkušenějších jedinců zajištuje přesnější replikaci předávaných kulturních informací z generace na generaci, a umožňuje jejich stabilizaci a postupnou kumulaci. ${ }^{22}$ Orientaci ve složitém socio-kulturním prostředí lidských sociálních skupin, imitaci relevantního obsahu a cílenou výuku usnadňuje dále rozvinutá lidská schopnost přisuzování mentálních stavů ostatním jedincům - čtení mysli (mindreading) či teorie mysli (theory of mind). ${ }^{23}$ Vysoká úroveň spolupráce a s tím spojená větší míra sociálního učení je rovněž podmíněna lidskou motivační stránkou spontánně se zapojovat do kooperativních interakcí. ${ }^{24}$

Přesnost kulturní transmise a uchovávání kulturních variant je dále formována nejen kognitivní, ale i motivačními předpoklady, které se projevují např́íklad ve specificky lidském způsobu komunikace. Člověk navazuje od rané fáze ontogeneze kooperativní způsob komunikace se svými sociálními partnery, během níž je spontánně informují o objektech a událostech, které vnímají jako potencionálně zajímavé či důležité. Ostatní hominidé $\mathrm{v}$ čele s šimpanzi naopak využívají komunikační gesta výhradně instrumentálně - tj. k dosažení vlastních cílů -, a proto mají spíše imperativní než informační charakter. ${ }^{25}$

${ }^{21}$ V literatuře sociálního učení je emulací označován jeden z typů sociálního učení, který je zaměřený výhradně na efekt pozorovaného chování. $V$ př́ípadě emulace se jedinec zaměřuje na porozumění konsekvence mezi chováním pozorovaného modelu a jeho následky. Na rozdíl od imitace tak během emulace nedochází $\mathrm{k}$ věrnému kopírování většiny sekvencí chování imitovaného modelu $\mathrm{k}$ dosažení kýženého efektu. Jedinec spoléhající na emulaci se naopak soustředí výhradně na dosažení stejného cíle, $\mathrm{k}$ čemuž zpravidla nevyžívá stejnou strategii jako pozorovaný model. Viz Andrew Whiten et al., „Emulation, Imitation, Over-Imitation and the Scope of Culture for Child and Chimpanzee," Philosophical Transactions of the Royal Society B: Biological Sciences 364, no. 1528 (2009): 2417-28.

${ }^{22}$ Hannah M. Lewis and Kevin N. Laland, „Transmission Fidelity Is the Key to the Build-up of Cumulative Culture," Philosophical Transactions of the Royal Society B: Biological Sciences 367, no. 1599 (2012): 2171-80.

${ }^{23}$ Esther Herrmann et al., „Humans Have Evolved Specialized Skills of Social Cognition: The Cultural Intelligence Hypothesis, “ Science 317, no. 5843 (2007): 1360-66.

${ }^{24}$ Felix Warneken and Michael Tomasello, „The Roots of Human Altruism,“ British Journal of Psychology 100, no. 3 (2009): 455-71.

${ }^{25}$ Michael Tomasello, A Natural History of Human Thinking (Cambridge, MA: Harvard University Press, 2014), 49-54 


\section{Hypotéza kolektivního mozku}

Za nejambicióznější rozvinutí předpokladů hypotézy kulturní inteligence lze označit hypotézu kolektivního mozku, která při popisu specifik lidské kognice využívá analogii struktury lidských společností a strukturálního uspořádání mozku, kde jsou individuální lidské subjekty připodobňovány $\mathrm{k}$ jednotlivým bodům $\mathrm{v}$ neuronových sítích. ${ }^{26}$

$\mathrm{Z}$ metodologického hlediska zasazuje hypotéza kolektivního mozku jedince vybavené kulturním mozkem (mozek primárně uzpůsoben k uchovávání a manipulaci s kulturními informacemi využitím rozličných forem strategií sociálního učení; viz 2. kapitola) do širšího sociálního kontextu a v rámci jejich vzájemné sociální interakce pak sleduje vývoj a obecnější tendence přenosu kulturních variant.

Otázka adaptability lidských skupin, které se spoléhají na kumulativní kulturní evoluci, je spjata s vysvětlením původu inovačního potenciálu lidské kultury, která člověku umožnila nejen se přizpůsobit nejrozmanitějším ekosystémům, ale propůjčila mu i schopnost radikálně transformovat a přizpůsobovat si prostředí, v němž žije. Zdrojem těchto inovací nejsou v podání hypotézy kolektivního mozku v první řadě kompetence individuální kognice, ale „chytrost“ distribuována napříc populací. Inteligentní design je vytvářen na základě selektivní transmise kulturních variant, kterou zajištuje na mikroúrovni sada kognitivních heuristik sociálního učení společně s procesem skupinové kulturní selekce. Zde se skrývá nejprovokativnější a zároveň nejproblematičtější teze celé hypotézy: proces výběru a inovace kulturních variant totiž podle hypotézy kolektivního mozku neprobíhá primárně vědomým rozhodováním jednotlivců. To znamená, že adaptivní hodnota imitovaných informací a chování není vyhodnocována na základě porozumění jejím kauzálním vztahům a funkčnosti, ale je zajištována „slepým“ procesem kulturní selekce:

Jednotlivci propojeni v kolektivních mozcích, kteří selektivně šiří a přijímají informace, mohou vytvářet, často na nevědomé úrovni, velice komplexní artefakty i bez působení nějakého inteligentního stvořitele - stejně jako přirozený výběr během biologické evoluce. ${ }^{27}$

Vysvětlení původu lidského inovačního potenciálu je $\mathrm{v}$ př́ípadě hypotézy kulturní inteligence z kognitivního hlediska méně náročná než konkurenční

\footnotetext{
${ }^{26}$ Muthukrishna and Henrich, „Innovation in the Collective Brain,"1-2.

${ }^{27}$ Muthukrishna and Henrich, „Innovation in the Collective Brain,“ 2 (překlad autor).
} 
prŕstupy (viz 1. kapitola). Zatímco tradice evoluční psychologie chápe lidskou mysl jako centrum inovačního potenciálu a inteligence člověka, které propojuje nezávislé a informačně zapouzdřené kognitivní moduly; hypotéza kulturní inteligence přesouvá tento mechanismus až na sociální úroveň. Inovační potenciál - zajištující vysokou míru adaptibility člověka - roste propojováním jednotlivých kulturních mozku do integrovaných sociálních celků. Hypotéza kolektivního mozku upozaduje při vysvětlování lidské adaptability na nejrozmanitější přírodní podmínky roli intencionálního jednání lidských aktérů a jejich porozumění, v čem přesně spočívá adaptivní hodnota jednotlivých kulturních praktik, které př̀jímají. Jako hlavní zdroj inovací vnímá primárně chyby, které vznikají jako nezamýšlený vedlejší produkt procesu kulturní transmise a individuálního učení.

Podle Henricha se původ velkého množství lidských vynálezů vzpírá široce rozšśřrené představě o primátu intelektuální činnosti individuálních géniů. Historie západní vědy je plná př́ikladů náhodných inovací, jakým je i objev bezpečnostního skla, které se stalo základním ochranným prvkem moderních dopravních prostředků. Francouzského chemika Eduoarda Benedicta $\mathrm{k}$ jeho vynálezu dovedla nehoda, která se odehrála $\mathrm{v}$ jeho chemické laboratoři, a socio-kulturní kontext rozvoje automobilové dopravy v první polovině 20. století. Při neobratné manipulaci s laboratorním vybavením upadla Benedictovi na zem prázdná baňka. $K$ jeho velkému překvapení se skleněná nádoba neroztrríštila do všech stran, jak očekával, ale její střepy zůstaly pohromadě. Po konzultaci se svým asistentem, jenž baňku zpětně zkoumal, došel $\mathrm{k}$ závěru, že tento efekt byl způsoben tekutým plastem, se kterým v laboratoři pracovali. Ten vytvořil na baňce tenký film, jež držel střepy pohromadě. Problémy spojené s rozvojem osobních motorových vozů v podobě vážných zdravotních rizik, které představovalo roztříštěné sklo během autonehod, otevřela novému objevu jeho praktické využití. ${ }^{28}$

Podle Muthukrishny a Henricha není př́iklad tohoto typu jen úsměvným anekdotickým př́iběhem a náhodnou deviací od typického průběhu vzniku inovativních řešení. Mnohé slavné objevy v oblasti chemie a farmacie, které se staly nedílnou součástí našeho každodenního života ( $\mathrm{v}$ čele s antibiotiky, plasty, teflonem, rentgenovým zářením atd.), vykazují výrazné strukturální podobnosti: jsou produktem nezamýšleného jednání, často

${ }^{28}$ Royston M. Roberts, Serendipity: Accidental Discoveries in Science (New York: Wiley, 1989), 155-59. 
při řešení naprosto odlišných problémů, a jejich funkčnost byla odhalena zpětně působením socio-kulturních vlivů. ${ }^{29}$

Další část inovativních řešení je prizmatem hypotézy kolektivního mozku výsledkem procesu tzv. kulturní rekombinace, který propojuje izolované informace a vytváří tím nové, komplexnější kulturní varianty. Tyto invence jsou výsledkem prolnutí trajektorií individuálních kulturních variant během jejich šírení v populaci u jednotlivců, kteří $\mathrm{k}$ nim mají často privilegovaný přístup. Tím hypotéza kolektivního mozku do značné míry redefinuje činnost objevitelů $\mathrm{v}$ procesu zrodu invencí. Namísto objevování nových kauzálních vztahů ve světě přisuzuje inovátorům především schopnost spojovat znalosti, kterým byli v průběhu svého života vystaveni prostřednictvím kulturního učení. Ukazuje se, že komplexnost okolního kulturního prostředí má pozitivní vliv na míru inovací. S rostoucím počtem kulturních modelů, které je možné imitovat, se totiž zvětšuje rezervoár nápadů, teorií, technologií, které je možné různě přetvářet a kombinovat. Tím dochází $\mathrm{k}$ jejich postupnému vylepšování. Mechanismus kulturní rekombinace lze rovněž dokumentovat na př́íladech vynálezů, které se nezávisle na sobě objevují ve stejné době na různých místech. ${ }^{30}$

Prominentní ukázkou procesu rekombinace je př́iběh teorie přirozeného výběru, která byla vymyšlena paralelně Charlesem Darwinem a Alfredem R. Wallacem. Jak poznamenává Muthukrishna, oba badatelé byli silně ovlivněni četbou stejných autorů (především Thomase R. Malthuse a Roberta Chamberse) a měli možnost účastnit se podobných výzkumných výprav do druhově pestrých oblastí. Rekombinační a více méně náhodný proces inovačního vývoje dává do popředí - namísto historických diskontinuit v podobě technologických revolucí - inkrementální inovace technologií, sociálních norem či institucí. ${ }^{31}$

Podle Henricha lidé spoléhají na systém kulturní transmise do takové míry, že jsou pomocí něho schopni ustálit i takovou lokální praxi, která je ve výsledku maladaptivní. Ke stabilizaci téměř libovolného typu chování stačí, pokud jsou členové sociální skupiny ve své většině přesvědčeni, že musí provádět určitý úkon $x$, a naopak trestají ty, kteří tak nečinní. Tato praxe bude stabilní do té doby, dokud náklady spojené $s$ trestem nepřekročí náklady s jeho prováděním. Je jedno, zda je daná praxe dlouhodobě pro-

\footnotetext{
${ }^{29}$ Muthukrishna and Henrich, „Innovation in the Collective Brain,“ 5 .

${ }^{30}$ Michael Muthukrishna et al., „Sociality Influences Cultural Complexity, “ Proceedings of the Royal Society B: Biological Sciences 281, no. 1774 (2013): 1-8.

${ }^{31}$ Muthukrishna and Henrich, „Innovation in the Collective Brain.“
} 
spěšná či destruktivní pro jednotlivce nebo skupinu, v obou př́padech se ji z krátkodobé perspektivy vyplatí následovat především kvůli potenciálnímu trestu. Proto sehrála podle Boyda a Richersona v historii rodu Homo důležitou roli skupinová kulturní selekce, která filtruje úspěšné normy, přesvědčení, technologie a instituce podporující stabilitu a provázanost celé sociální skupiny. Mezi hlavní mechanizmy kulturní skupinové selekce, díky nimž se prosazují adaptivní kulturní varianty na úkor méně úspěšných lokálních praxí, podle nich patří: 1) meziskupinová kompetice: některé skupiny mají díky svým institucím technologickou, vojenskou a ekonomickou dominanci; 2) virulence - některé skupiny díky svým institucím a sociálním normám dokáží lépe čelit různým ekologickým výzvám nebo úskalím možných konfliktů uvnitř skupiny; 3 ) migrace: úspěšné skupiny mohou lákat migranty z ostatních, méně úspěšných skupin; 4) různá míra reprodukce - stabilní prostředí zajištuje lepší možnosti pro reprodukci - skupiny s větším počtem členů mají tendenci expandovat na úkor stagnujících. ${ }^{32}$

\section{Chytrost bez porozumění?}

Hypotéza adaptivní inteligence vysvětluje bezprecedentní míru inovativních řešení u člověka prostřednictvím doménově-specifických kognitivních schopností, které společně vytvářejí jedinečný prostor lidské kognitivní niky. V tomto prostoru je pak možné např́ílad pomocí procesu kauzálního uvažování simulovat mentální modely vnějšího světa, které slouží $\mathrm{k}$ vývoji nových technologických vynálezů, norem a institucí. Kulturní varianty jsou $\mathrm{v}$ tomto př́padě imitovány a uchovávány na základě porozumění mechanismu, jenž je zodpovědný za to, že je přejímaná praxe či jednání v určitém kontextu adaptivní. Pohledem hypotézy adaptivní inteligence se za procesem kulturní evoluce skrývá v první řadě série individuálních rozhodnutí lidských jedincủ, kteří konstruují, hodnotí a přejímají nové invence posouzením jejich adaptivní hodnoty. ${ }^{33}$

Hypotéza kulturní inteligence si při popisu lidské adaptability vystačí s minimalističčějším mechanismem kulturní transmise a sadou jednoduchých heuristik sociálního učení. Adaptabilita přenosu kulturních variant je vysvětlována prostřednictvím selektivního modelu kulturní evoluce,

${ }^{32}$ Robert Boyd, Peter J. Richerson, and Joseph Henrich, „Rapid Cultural Adaptation Can Facilitate the Evolution of Large-Scale Cooperation," Behavioral Ecology and Sociobiology 65, no. 3 (2011): 431-44.

${ }^{33}$ Viz Steven Pinker, „The Cognitive Niche: Coevolution of Intelligence, Sociality, and Language," Proceedings of the National Academy of Sciences 107 (2010): 8993-9. 
který částečně přejímá schéma biologické evoluce, ačkoliv oba mechanismy nefungují izomorfně. Selektivní model kulturní evoluce pracuje s mechanismem replikace kulturních variant, které jsou během procesu transmise částečně zkreslovány a upravovány; dále selekcí nejúspěšnějších variant prostřednictvím sady kognitivního zkreslení a jejich udržování napříc generacemi procesem imitace a výuky.

Dalším důležitý atributem biologické evoluce, který model kulturní evoluce přejímá, představují její metodologické předpoklady $\mathrm{v}$ podobě populační perspektivy. Zkoumané makrojevy (kulturní tradice, rituály, instituce) jsou vysvětlovány na úrovni kauzálního popisu mikroevolučních mechanismů: dynamika kulturní evoluce je popisována funkcemi sociálního učení, které ovlivňují podobu a směr kulturního přenosu. Selekcionistické modely kulturní evoluce pracují s předpokladem, že jednající subjekty imitují a přenášejí kulturní varianty více méně „slepě“ - bez podrobnější znalostí výhod a nákladu, které jsou s nimi obsahově spojeny. Tím upozadují rovinu vědomého lidského jednání a přímočařeji propojují makroúroveň sociálních jevů s podvědomými kognitivními mechanismy.

Zastánci hypotézy kulturní inteligence demonstrují fungování kulturní inteligence nejen prostřednictvím formálních matematických modelů, ale na množství empirického materiálu etnografických výzkumů. Prominentní př́ílad mechanismu kulturní inteligence představuje výzkum tabu na Fidži, který se svým týmem popsal Joseph a Natalie Henrichovi. V tamních společnostech je rozšířené tabu vztahující se na konzumaci určitých druhů mořských živočichů během těhotenství a laktace. Pokrmy připravované $\mathrm{z}$ těchto živočišných druhů jsou sice výživově bohaté a oblíbené mezi místními, ale vyskytuje se u nich vyšší riziko přítomnosti ciguatoxinů, které jsou obzvlášt nebezpečné pro zdravý vývoj dětského plodu. Pokud mají místní ženy zdůvodnit, proč nepřijímají dané pokrmy během těhotenství, často nedokážou vysvětlit př́padné následky, které by porušení tabu s sebou neslo. Fidžijské ženy přejímají tuto obecně sdílenou sociální normu, čímž výrazně snižují nebezpečí poškození plodu, i přesto, že nerozumí kauzálnímu mechanismu negativního působení toxinů. Jednoduše využívají konformní strategii sociálního učení a bezděčně si osvojují vysoce adaptivní kulturní praktiku. ${ }^{34}$ Hypotéza kulturní inteligence v podání zastánců podvojné dědičnosti chápe jako hlavní prř́činu lidské behaviorální flexibility schopnost

\footnotetext{
${ }^{34}$ Joseph Henrich and Natalie Henrich. „The Evolution of Cultural Adaptations: Fijian Food Taboos Protect Against Dangerous Marine Toxins," Proceedings of the Royal Society B: Biological Sciences 277, no. 1701 (2010): 3715-24.
} 
orientovat se pomocí jednoduchých kognitivních heuristik sociálního učení a kulturního učení v nepřehledné spleti podnětů z fyzického a sociálního prostředí, ve kterých je velice obtížné a nákladné sledovat př́mo kauzální vztahy mezi pozorovanými jevy v procesu individuálního učení.

Jsou tyto „hloupé“ heuristiky sociálního učení hlavním rysem lidské schopnosti flexibilní adaptace na vnější prostředí, nebo se jedná spiše o specifický př́pad? A jakou roli při něm hraje individuální inteligence sociálních aktérư? Morin ve své knize How Traditions Live and Die ${ }^{35}$ tvrdí, že tradice teorie podvojné dědičnosti ( $\mathrm{z}$ níž vychází i hypotéza kolektivního mozku), pracuje př̀ popisu kulturní transmise s modelem tzv. kompulzivní imitace: lidé spontánně kopírují chování imitovaných modelů, které jsou selektovány výhradně prostř̌ednictvím jednoduchých strategií sociálního učení v čele $s$ konformním zkreslením a zkreslením prestiže. A to nejen v případech, kdy je složité sledovat příčinné vztahy mezi určitým jednáním a jeho následky, ale i v situacích, kdy mají k dispozici vlastní, spolehlivější informace, které jsou získány pomocí individuálního učení nebo sociálního učení v minulosti. Podle Morina tento obraz kulturní transmise a lidského rozhodování sice konvenuje formálnímu selekcionistickému modelu kulturní evoluce, ale ve skutečnosti je příliš zjednodušující. ${ }^{36}$

Morin tvrdí, že mechanismus kulturní transmise a lidského rozhodování lépe charakterizuje model flexibilní imitace. Ten, na rozdíl od strategie kompulzivní imitace, zahrnuje i metakognitivní schopnost vyhodnocovat spolehlivost vlastních informací v porovnání s informacemi imitovaných modelů a umožňuje selektivně využívat různé strategie učení podle nastalého kontextu. Podle Morina modely kulturního učení často pracují s falešným dilematem, kdy jednající může využívat bud’ na jedné straně kulturní informace, nebo individuální učení, bez možnosti tyto strategie vzájemně kombinovat. Strategie sociálního a asociálního učení se však nemusí nutně vzájemně vylučovat: lidé mohou zároveň sledovat potenciální zdroje adaptivních informací ze svého sociálního prostředí a porovnávat je případně s vlastními zkušenostmi. Takový typ sociálního učení s sebou samozřejmě nese větší kognitivní zátěž. $Z$ toho důvodu je flexibilní učení aplikováno primárně v situacích, ve kterých se vyšší kognitivní a časové náklady vyplatí. Podle Morina experimentální studie dokazují, že lidé vybírají pečlivěji mezi zdroji informací, kterým důvěřují. Nejmarkantněji se pak tato tendence pro-

${ }^{35}$ Olivier Morin, How Traditions Live and Die (Oxford: Oxford University Press, 2016).

${ }^{36}$ Olivier Morin, ,Reasons to Be Fussy about Cultural Evolution," Biology and Philosophy 31, no. 3 (2016): 447-58. 
jevuje v př́padech, kdy toto rozhodování spojeno s potenciálně závažnými konsekvencemi (např̀ pro zdraví sebe a svých dětí). ${ }^{37}$

Strategické vyhodnocování vhodných strategií učení a kulturních variant lze dokumentovat na výzkumech konformního zkreslení. Výzkumy lidské konformity z 50. let minulého století - z nichž nejznámější je tzv. Aschův experiment- ukazují zásadní vliv sociálního prostředí na lidské rozhodování. Model Ashova experimentu vypadá následovně: osmi účastníkům výzkumu jsou ukázány dvě karty: na první z nich se nachází jedna vertikální přímka; na druhé kartě jsou tři různě dlouhé vertikální př́ímky a jedna $\mathrm{z}$ nich je identická s př́mkou z první karty. Úkolem účastníkủ je poté označit př́mky se stejnou velikostí $z$ obou karet s tím, že na konci každého kola experimentu oznamují veřejně přede ostatními svoji odpověd'. Nejdůležitějším prvek celého Ashova experimentu je cílená sociální manipulace účastníků, která je docílena tím, že $z$ oněch osmi osob účastnících se výzkumu je pouze jeden $\mathrm{z}$ nich opravdovým probandem - zbylých sedm ve skutečnosti spolupracuje s výzkumníky. Ưkolem figurantů je v domluvených případech záměrně zvolit špatnou odpověd', tj. označit za stejné dvě různě dlouhé přímky. Cílem Ashova experimentu je zkoumat, jak bude na tento sociální tlak reagovat nic netušící účastník výzkumu. A jeho výsledky naznačují, že sociální prostředí a konformita má na lidské rozhodování enormní vliv. Pokud „falešni“ účastníci schválně zvolili špatnou odpověd, většina probandů se této špatné volbě podvolila, i když v jiných kolech experimentu, ve kterých byly odpovědi figurantů různorodější, identifikovali bez problémů správnou variantu. Původní Aschův experiment implikuje, že se lidský sklon ke konformnímu jednání a imitaci většiny projevuje i v prrípadech, kdy jsou názory většiny v jasném rozporu s výsledky individuálního učení. ${ }^{38}$

Tato tendence se však začne výrazně měnit, jestliže je lidské rozhodování spojeno s náklady. Robert Baron se svým týmem pozměnil klasické schéma Ashova experimentu - namísto přímek měli účastníci experimentu za úkol identifikovat osobu $\mathrm{v}$ řadě lidí, kterou mohli předtím vidět na obrázku. Probandům bylo $\mathrm{v}$ jednotlivých kolech přiděleno rozdílné penzum času na identifikaci osob a jejich odpovědi byly spojeny s určitou finanční odměnou. Robert Baron a jeho tým dospěli $\mathrm{k}$ jinému výsledku než Asch. Účastníci výzkumu se v této verzi výzkumu rozhodovali strategičtěji a flexibilněji v návaznosti na kontext: 1) pokud měli málo času na identifikaci

\footnotetext{
${ }^{37}$ Morin, How Traditions Live and Die, 87-104.

${ }^{38}$ Solomon E. Asch, „Studies of Independence and Conformity: I. A Minority of One against a Unanimous Majority,“ Psychological Monographs: General and Applied 70, no. 9 (1956): 1-70.
} 
správné odpovědi, uchylovali se ke konformní strategii učení; 2) v situaci, kdy měli dostatek času a mohli zjistit spolehlivé informace sami, drželi se ve větší míře výsledku individuálního učení. Navíc byla tato tendence silnější v př́ípadech, kdy byly správné výsledky spojené s finanční odměnou: probandi s narůstajícími náklady, které by plynuly z potenciálně chybného rozhodnutí, mnohem pečlivěji rozvažovali své strategie. ${ }^{39}$

Kim Sterelny používá k popisu lidského způsobu sociálního učení termín hybridního učení, který propojuje sociální a asociální učení v závislosti na samotné povaze imitovaného jevu a vlastnostech sociálního prostředí. Jejich podíl se liší v jednotlivých kulturních sférách: např́klad v oblasti transmise nástrojových technik, u kterých je mnohem snazší sledovat přímí efekt předávaných informací (např̀. v podobě návodů na jejich konstrukci a manipulaci), testovat jejich účinnost a př́padně je modifikovat, bude hrát individuální učení větší roli než $\mathrm{v}$ prrípadě medicínských znalostí, u nichž je velice složité sledovat kauzální řetězec a funkčnost jednotlivých kroků a technik. Sterelny vnáší do celé debaty o povaze sociálního učení a kulturní transmise další evoluční rozměr. Podle něj mohly být „hloupé“ strategie sociálního učení dominantním prvkem lidské adaptace ve fázi lidské historie, během níž bylo nadmíru složité vybudovat jakoukoliv sociální infrastrukturu zkoumání, přenosu a uchovávání informací, která by snižovala náklady spojené s individuálním učením. S rostoucím stupněm komplexity lidských společností a vyšší mírou dělby práce se mohla závislost na jednoduchých strategiích sociálního učení snižovat. ${ }^{40}$

Je samozřejmě otázkou, do jaké míry jsou tyto výtky na adresu teorií podvojné dědičnosti oprávněné a do jaké míry se jedná spíše o „slaměného panáka“. Sám Morin přiznává, že proponenti teorie podvojné dědičnosti ve svých modelech neredukují sociální učení pouze na konformní zkreslení a zkreslení prestiže a nechávají prostor pro určitou flexibilitu lidské individuální inteligence ve vztahu k výběru strategií sociálního učení. Např. Boyd a Richerson tvrdí podobně jako Morin, že lidé spoléhají na jednoduchá imitační pravidla pouze $\mathrm{v}$ situacích, kdy je těžké a nákladné analyzovat adaptivní hodnotu alternativních kulturních variant. Důležitou roli řízené

\footnotetext{
${ }^{39}$ Robert S. Baron, Joseph A. Vandello, and Bethany Brunsman, „The Forgotten Variable in Conformity Research: Impact of Task Importance on Social Influence," Journal of Personality and Social Psychology 71, no. 5 (1996): 915-27.

${ }^{40}$ Kim Sterelny, „Cultural Evolution in California and Paris, “Studies in History and Philosophy of Science Part C: Studies in History and Philosophy of Biological and Biomedical Sciences 62 (2017): 42-50.
} 
variaci přiznávají i Muthukrishna a Henrich při popisu vzniku a vývoje náhodných invencí:

Nicméně je potřeba podotknout, že $\mathrm{v}$ každém $\mathrm{z}$ těchto případů [náhodných objevů - pozn. aut.] byla mysl vynálezce připravena rozpoznat objev ukrytý v náhodném pozorování. ${ }^{41}$

Avšak větší role flexibilního a hybridního učení by hypotézu kulturní inteligence přibližovalo adaptivním přístupům favorizující prominentní roli individuální inteligence při vysvětlování lidské adaptability. Kulturní evoluce postavená ve velké míře na řízené variaci by systematicky snižovala význam kulturní selekce, jejíž funkce je podmíněna „hloupými“ strategiemi sociálního učení imitujícími kulturní obsah bez výrazných modifikací individuálních imitátorů na základě analýzy adaptivní hodnoty jejich obsahu. Tím by se výrazně oslabila hlavní teze kulturní inteligence, která tvrdí, že kultura je chytřejší než inteligence samotných jedinců.

\section{Metakognitivní strategie sociálního učení}

Modely flexibilní a hybridní imitace propojují mechanismus kulturního přenosu těsněji s individuálním obrazem funkce lidské kognice podobným teoriím duálních procesů: kulturní transmise je ovlivňována jak na jedné straně doménově-specifickými moduly, tak i epistemickou funkcí metakognitivního procesu uvažování vyhodnocující důvěryhodnost informačních zdrojů a jejich obsah. Proces kulturní transmise se zdá být tímto prizmatem mnohem chytřejší, než naznačuje hypotéza kolektivního mozku, a ve výsledku konformní představě člověka jako vesměs racionálního aktéra, který je vlastní obecným a adaptivním hypotézám lidské inteligence.

Možnou cestu, jak na jedné straně zachovat stěžejní předpoklady hypotézy kulturní inteligence i v př́padě zapojení metakognitivních procesů představuje ve svých článcích Cecilia Heyesová. Ta rozlišuje dva druhy strategií sociálního učení podle jejich komplexity a odlišných psychologických mechanismů, které podmiňují jejich fungování. První z nich jsou tzv. planetární pravidla, ${ }^{42}$ která fungují na jednoduchém principu asociativního učení, jsou doménově-obecná a spouštějí se automaticky na nevědomé

\footnotetext{
${ }^{41}$ Muthukrishna and Henrich, „Innovation in the Collective Brain,“ 5 (překlad autor).

${ }^{42}$ Heyesová používá pojem planetárních pravidel z toho dủvodu, že existují primárně v hlavách samotných vědcủ nežli v myslích popisovaných jedincủ, kteří by se podle nich řídili, podobně jako fyzikální zákony existují především v teoriích, a nikoliv v pomyslném vědomí
} 
úrovni. Podle Heyesové mnohé výzkumy napřič jednotlivými živočišnými druhy naznačují, že psychologické mechanismy řídící strategie učení byly primárně selektovány za účelem zpracovávání podnětů k získávání relevantních poznatků jak ze sociálního, tak i fyzického prostředí. Proto je sociální učení u většiny druhů a $\mathrm{z}$ velké části i u člověka řízeno stejnými psychologickými mechanismy a pravidly rozhodování jako učení individuální. Z toho důvodu lze velkou část popsaných pravidel sociálního učení (viz 2. kapitola) vysvětlit prostřednictvím planetárních pravidel. Např́ílad kontextuální pravidla sociálního učení (kognitivní zkreslení věku a prestiže) lze podle Heyesové vysvětlit pomocí doménově-obecného systému pozornosti (tj. systému, který není specializovaný výhradně na sociální učení) a asociativního učení. Jedinci, kteří na sebe dokážou upoutat více pozornosti - mají větší výšku, projevují se hlasitěji nebo se nacházejí blíže požadovanému objektu jsou ve větší míře napodobováni než ti, kteři takovou pozornost nevzbuzují. Tyto systémy jsou i přes svoji jednoduchost efektivní v navigaci sociálního a asociálního učení ke zdrojům adaptivních informací, které navíc pružně reagují na změny prostředí. Proto je možné pozorovat příklady sociálního učení u mnoha živočišných druhů. ${ }^{43}$

Pravidla sociálního učení v pravém smyslu slova odpovídají spíše sofistikovanějšímu psychologického mechanismu tzv. metakognitivních strategií sociálního učení, které podle Heyesové nacházíme pouze u člověka. Na rozdíl od planetárních pravidel jsou doménově-specifická, pracují na vědomé úrovni a objevují se v pozdějších fázích lidské ontogeneze. Jejich hlavním úkolem je určit podmínky, za kterých je vhodné použít sociální namísto asociálního učení, a od koho prrípadně sociální informace získávat. Provádějí tedy supervizi procesu sociálního učení a směřují ho určitým směrem podle specifických pravidel. Heyesová připodobňuje metakognitivní pravidla sociálního učení $\mathrm{k}$ receptům a lidi ke kuchařům, kteří se jimi řídí při přípravě jídla - na rozdíl od planet si jsou lidé vědomi pravidel, kterým přizpůsobují své chování. Heyesová tvrdí, že většina popsaných strategií sociálního učení $\mathrm{v}$ tradici ekonomie a behaviorální ekologie v sobě již implicitně obsahuje určitý metakognitivní rozměr v tom smyslu, že navádí naše jednání směrem k sociálním zdrojům na základě metakognitivní analýzy, která informuje

samotných vesmírných objektů. Viz Cecilia Heyes, „Who Knows? Metacognitive Social Learning Strategies, “Trends in Cognitive Sciences 20, no. 3 (2016): 204-13.

${ }^{43}$ Cecilia Heyes, „Enquire Within: Cultural Evolution and Cognitive Science,“ Philosophical Transactions of the Royal Society B: Biological Sciences 373, no. 1743 (2018): 1-9; Heyes, „Who Knows ?“; Cecilia Heyes, „When Does Social Learning Become Cultural Learning?,“ Developmental Science 20, no. 2 (2017): 1-14. 
jednajícího, že jeho vlastní znalosti jsou nedostatečné, nebo naopak nespolehlivé. Pravidla typu „kopíruj většinu“ tak ve skutečnosti říkají „kopíruj většinu, pokud má většina lepší znalosti než ty.“ Metakognitivní pravidla však nehodnotí kvalitu samotných kulturních variant, ale provádí primárně analýzu kontextuálních faktorů. ${ }^{44}$

Co je však nejdůležitější, strategie sociálního učení jsou podle Heyesové - podobně jako ostatní metakognitivní pravidla - osvojována v procesu sociálního učení. Lidé se během svého života učí množství specifických pravidel rozhodování, jež jsou závislá na určitém kulturním kontextu. ${ }^{45}$ Heyesová uvádí příklad amerických absolventů a absolventek humanitních a sociálně-vědních oborủ, kteří v porovnání $s$ absolventy př́rodovědeckých disciplín přikládají větší důvěru výzkumům, v nichž se objevují jakékoliv matematické vzorce, které však nemusejí mít žádnou logickou spojitost se zbytkem textu. ${ }^{46}$ Heyesová tvrdí, že absolventi humanitních a sociálně-vědních oborů se při rozhodování o relevanci předkládaných výzkumů řídí naučeným pravidlem typu „matematika dělá vědu přesnějši“", kterou si osvojili ze svého sociálního prostředí. Podobně se lidé učí, komu a za jakých podmínek důvěřovat $\mathrm{v}$ oblastech mimo svoji expertízu pomocí pravidel typu "důvěřuj mechanikovi při opravě auta“ či „doktor rozumí funkcím těla. ${ }^{477}$

Metakognitivní pravidla sociálního učení v sobě zahrnují určitou evoluční dynamiku, kdy se s nárůstem komplexity sociálního prostředí zvyšuje rovněž dělba práce a oborová specializace, což zvyšuje tlak na schopnosti spojené s identifikací důvěryhodných informačních zdrojů. Samozřejmě často bez reálné možnosti zhodnotit samotný obsah, který je nám nabízen, protože dalece přesahuje naši vlastní odbornost a reálnou možnost je ověřit. Metakognitivní pravidla umožňují tuto situaci efektivně řešit na základě škály jednoduchých pravidel, které mohou být kontextuálně vymezeny pro určitou oblast (napřr. „kopíruj jedince s kvalifikací v určitém oboru“).

I přes to, že jsou kognitivně náročná, splňují podle Heyesové metakognitivní pravidla sociálního učení předpoklady kulturní selekce: jsou „hloupé" v tom smyslu, že selektují určité typy kulturních variant bez toho, aby jednající musel vědět, která z nich je adaptivní, a která nikoliv:

\footnotetext{
${ }^{44}$ Heyes, „Enquire Within.“

${ }^{45}$ Nicholas Shea et al., "Supra-Personal Cognitive Control and Metacognition," Trends in Cognitive Sciences 18, no. 4 (2014): 186-93.

${ }^{46}$ Kimmo Eriksson, „The Nonsense Math Effect,“ Judgment and Decision Making 7, no. 6 (2012): 746-49.

${ }^{47}$ Heyes, „When Does Social Learning Become Cultural Learning?“
} 
[Metakognitivní pravidla sociálního učení - pozn. aut.] Jsou alternativou k přímému/obsahovému zkreslení, která nechává prostor kulturní selekci - spíše než individuální inteligenci - při výběru adaptivního jednání. Pokud imituji stavitele lodí s největší flotilou, existuje velká pravděpodobnost, že budu zároveň kopírovat konstrukci, která je obzvlášt úspěšná. A to z toho důvodu, že početná flotila si udržuje svoji velikost, když je tvořena lod’mi, u nichž je méně pravděpodobné, že se potopí. Ale zcela zásadní je skutečnost, že nepotřebuji znát tento fakt k výběru správného - adaptivního - rozhodnutí, který typ konstrukce lodi imitovat. ${ }^{48}$

Hlavní výhodou metakognitivních pravidel sociálního učení je vyšší přesnost, se kterou dokážou identifikovat zdroj adaptivních kulturních variant. Zatímco planetární pravidla jsou produktem pouze doménově-obecného mechanismu asociativního učení a individuálního učení, metakognitivní pravidla využívají potenciálu kolektivně sdílených znalostí v rámci jednotlivých sociálních skupin. Zároveň udržují přesnost kulturních variant během procesu sociálního učení. Tím, že specifikují, od koho a v jaké oblasti získávat potenciálně adaptivní informace, zároveň odrazují imitátory od řízené variace - vytváření a modifikace kulturních variant na základě individuálního učení. To nutně přispívá k uchovávání identity kulturních variant v procesu transmise, které se mohou stát předmětem kulturní selekce. ${ }^{49}$

Heyesová ukazuje, že strategie sociálního učení stojí nejen v samotných základech kumulativní kulturní evoluce, ale stávají se samy jejím předmětem: metakognitivní pravidla podléhají mechanismu kulturní selekce podobně jako kulturní varianty. Pravidla rozhodování rídící proces sociálního učení nemusí být nutně produktem jednoduchých kognitivních instinktů, nebo individuálního učení. Svoji nezastupitelnou roli v procesu adaptace člověka na komplexní prostředí mohla sehrát i kulturní inteligence přesahující oblast individuální kognice.

\section{Závěr}

Hypotéza kulturní inteligence zapadá do mozaiky přístupů, které obrací svoji pozornost při studiu lidské kognice směrem k dynamice sociálního prostředí lidských skupin a jejich vlivu na vývoj lidského myšlení. V porovnání s konkurenčními teoriemi obecné a adaptivní hypotézy inteligence

${ }^{48}$ Heyes, „Enquire Within,“ 18 (překlad autor).

${ }^{49}$ Ibid. 
označuje za hlavní původ lidského inovativního potenciálu proces kumulativní kulturní evoluce. Pomocí něj se v prostoru sdílených kulturních tradic postupně shromaždují adaptivní kulturní informace, které jsou zachovávány a dále rozvíjeny mechanismem kulturního učení (imitace, výuka, teorie mysli, kognitivní zkreslení atd.). Z těchto premis vyplývá, že lidská inteligence netkví primárně ve schopnostech individuální kognice, ale je realizována na úrovni tzv. kolektivního mozku: lidé si často osvojují rozličné adaptivní kulturní varianty na základě jednoduchých strategií sociálního učení bez toho, aby rozuměli samotnému kauzálnímu mechanismu, který se skrývá za funkčností přejímaných kulturních praktik. Výzkum zdroje lidské flexibilní adaptace by se neměl zaměřovat pouze na vztah intuitivních kognitivních instinktů a metakognitivních/reflektivních schopností, ale měl by svůj záběr rozšíriit rovněž na fenomén kulturního učení, který sehrál svoji nezastupitelnou roli v naší evoluční historii.

$\mathrm{V}$ tomto článku jsem se snažil poukázat na určitou tenzi v teoretickém základu hypotézy kulturní inteligence. Jak ukazuje Morin se Sterelnym, lidské formy sociálního učení se nedají popsat pouze na základě strategií sociálního učení $\mathrm{v}$ čele $\mathrm{s}$ kognitivním zkreslením prestiže a konformity. Mnohem pravděpodobnější obraz mechanismu kulturního přenosu nabízí flexibilní imitace, která předpokládá zapojení netriviálních kognitivních kapacit. Avšak, jakýkoliv posun směrem k flexibilnějšímu typu kulturního učení podrývá hlavní předpoklady selektivního modelu kulturní evoluce („hloupost“ a přesnost kulturní transmise). Pokud by lidé na individuální úrovni rozhodovali o adaptivní hodnotě jednotlivých kulturních variant, pak bychom si vystačili při popisu kulturní evoluce s nějakou verzí adaptivní hypotézy.

Cecilia Heyesová představuje způsob, jak by bylo možné vzájemně skloubit předpoklady hypotézy kulturní inteligence s flexibilnějšími typy kulturní transmise prostřednictvím metakognitivních strategií sociálního učení. Ty jsou samy produktem kulturní evoluce a $\mathrm{k}$ jejich osvojování dochází postupně v procesu kulturního učení, čímž si zachovávají potřebnou plastičnost. Zároveň jsou však „hloupé“ $\mathrm{v}$ tom smyslu, že selektivně směřují pozornost imitátorů $\mathrm{k}$ potenciálně adaptivním kulturním variantám pomocí kontextuálních charakteristik sociálních modelů („kopíruj většinu“, „kopíruj nejprestižnější/nejprestižnějšího atd.). 


\section{Bibliografie:}

Asch, Solomon E. „Studies of Independence and Conformity: I. A Minority of One Against a Unanimous Majority." Psychological Monographs: General and Applied 70, no. 9 (1956): 1-70. https://doi.org/10.1037/h0093718.

Barkow, Jerome H., Leda Cosmides, and John Tooby. The Adapted Mind: Evolutionary Psychology and the Generation of Culture. New York: Oxford University Press, 1992.

Baron, Robert S., Joseph A. Vandello, and Bethany Brunsman. „The Forgotten Variable in Conformity Research: Impact of Task Importance on Social Influence." Journal of Personality and Social Psychology 71, no. 5 (1996): 915-27. https://doi.org/10.1037/0022-3514.71.5.915.

Boyd, Robert, and Peter J. Richerson. Culture and the Evolutionary Process. Chicago: University of Chicago Press, 1985.

Boyd, Robert, Peter J. Richerson, and Joseph Henrich. „Rapid Cultural Adaptation Can Facilitate the Evolution of Large-Scale Cooperation." Behavioral Ecology and Sociobiology 65, no. 3 (2011): 431-44. https://doi.org/10.1007/s00265-010-1100-3.

Byrne, Richard. The Thinking Ape: Evolutionary Origins of Intelligence. Oxford: Oxford University Press, 1995.

Chudek, Maciej, and Joseph Henrich. „Culture-Gene Coevolution, NormPsychology and the Emergence of Human Prosociality. Trends in Cognitive Sciences 15, no. 5 (2011): 218-26. https://doi.org/10.1016/j.tics.2011.03.003.

Cosmides Leda, and John Tooby. „Unraveling the Enigma of Human Intelligence: Evolutionary Psychology and the Multimodular Mind.“ The Evolution of Intelligence, no. 67 (2001): 145-98.

Ehn, Micael, and Kevin Laland. „Adaptive Strategies for Cumulative Cultural Learning." Journal of Theoretical Biology 301 (2012): 103-11.

https://doi.org/10.1016/j.jtbi.2012.02.004.

Eriksson, Kimmo. „The Nonsense Math Effect.“ Judgment and Decision Making 7, no. 6 (2012): 746-49.

Henrich, Joseph. The Secret of Our Success: How Culture Is Driving Human Evolution, Domesticating Our Species, and Making Us Smarter. Princeton, NJ: Princeton University Press, 2016.

Herrmann, Esther, Josep Call, María Victoria Hernández-Lloreda, Brian Hare, and Michael Tomasello. „Humans Have Evolved Specialized Skills of Social Cognition: 
The Cultural Intelligence Hypothesis.“ Science 317, no. 5843 (2007): 1360-66. https://doi.org/10.1126/science.1146282.

Heyes, Cecilia. „Cognitive Gadgets: The Cultural Evolution of Thinking." Cognitive Gadgets: The Cultural Evolution of Thinking. Cambridge, MA: Harvard University Press, 2018. https://doi.org/10.4159/9780674985155.

Heyes, Cecilia. „Enquire within: Cultural Evolution and Cognitive Science.“ Philosophical Transactions of the Royal Society B: Biological Sciences 373, no. 1743 (2018): 1-9. https://doi.org/10.1098/rstb.2017.0051.

Heyes, Cecilia. „When Does Social Learning Become Cultural Learning?“ Developmental Science 20, no. 2 (2017): 1-14. https://doi.org/10.1111/desc.12350.

Heyes, Cecilia. „Who Knows? Metacognitive Social Learning Strategies.“ Trends in Cognitive Sciences 20, no. 3 (2016): 204-13. https://doi.org/10.1016/j.tics.2015.12.007.

Hoppitt, William, and Kevin N. Laland. Social Learning: An Introduction to Mechanisms, Methods, and Models. Princeton, NJ: Princeton University Press, 2013.

Kappeler, Peter M., Joan B. Silk, eds. Mind the Gap: Tracing the Origins of Human Universals. Berlin: Springer, 2010.

Köhler, Wolfgang. The Mentality of Apes. New York: Liveright, 1976.

Laland, K. N., F. J. Odling-Smee, and M. W. Feldman. „The Evolutionary Consequences of Niche Construction: A Theoretical Investigation Using TwoLocus Theory.“ Journal of Evolutionary Biology 9, no. 3 (1996): 293-316. https://doi.org/10.1046/j.1420-9101.1996.9030293.x.

Lewis, H. M., and K. N. Laland. „Transmission Fidelity Is the Key to the Build-up of Cumulative Culture." Philosophical Transactions of the Royal Society B: Biological Sciences 367, no. 1599 (2012): 2171-80. https://doi.org/10.1098/rstb.2012.0119.

Mace, Ruth, Clare Holden, and Stephen Shennan. „The Evolution of Cultural Diversity: A Phylogenetic Approach." The Evolution of Cultural Diversity: A Phylogenetic Approach, edited by Ruth Mace, Clare J. Holden, and Stephen Shennan. Walnut Creek, US: Left Coast Press, 2005.

Morin, Olivier. How Traditions Live and Die. Oxford: Oxford University Press UK, 2016.

Morin, Olivier. „Reasons to Be Fussy about Cultural Evolution.“ Biology and Philosophy 31, no. 3 (2016): 447-58. https://doi.org/10.1007/s10539-016-9516-4. 
Muthukrishna, M., B. W. Shulman, V. Vasilescu, and J. Henrich. „Sociality Influences Cultural Complexity." Proceedings of the Royal Society B: Biological Sciences 281, no. 1774 (2013): 1-8. https://doi.org/10.1098/rspb.2013.2511.

Muthukrishna, Michael, and Joseph Henrich. „Innovation in the Collective Brain.“ Philosophical Transactions of the Royal Society B: Biological Sciences 371, no. 1690 (2016): 1-14. https://doi.org/10.1098/rstb.2015.0192.

Pinker, Steven. „The Cognitive Niche: Coevolution of Intelligence, Sociality, and Language." Proceedings of the National Academy of Sciences 107 (2010): 8993-9. https://doi.org/10.1073/pnas.0914630107.

Richerson, Peter J., a Robert Boyd. V genech není všechno, aneb, Jak kultura změnila evoluci člověka. Praha: Academia, 2012.

Roberts, Royston M. Serendipity: Accidental Discoveries in Science. New York: Wiley, 1989.

Rogers, Alan R. „Does Biology Constrain Culture.“ American Anthropologist 90, no. 4 (1988): 819-31. https://doi.org/10.1525/aa.1988.90.4.02a00030.

Schaik, Carel P. van, and Judith M. Burkart. „Social Learning and Evolution: The Cultural Intelligence Hypothesis." Philosophical Transactions of the Royal Society B: Biological Sciences 366, no. 1567 (2011): 1008-16.

https://doi.org/10.1098/rstb.2010.0304.

Schmidt, Marco F. H., and Michael Tomasello. „Young Children Enforce Social Norms." Current Directions in Psychological Science 21, no. 4 (2012): 232-36. https://doi.org/10.1177/0963721412448659.

Shea, Nicholas, Annika Boldt, Dan Bang, Nick Yeung, Cecilia Heyes, and Chris D. Frith. „Supra-Personal Cognitive Control and Metacognition." Trends in Cognitive Sciences 18, no. 4 (2014): 186-93. https://doi.org/10.1016/j.tics.2014.01.006.

Sterelny, Kim. „Cultural Evolution in California and Paris.“ Studies in History and Philosophy of Science Part C: Studies in History and Philosophy of Biological and Biomedical Sciences 62 (2017): 42-50. https://doi.org/10.1016/j.shpsc.2016.12.005.

Thaler, Richard H., a Cass R. Sunstein. Nudge (Štouch): Jak postrčit lidi k lepšímu rozhodování o zdraví, majetku a štěstí. Zlín: Kniha Zlín, 2010.

Tomasello, Michael, and Josep Call. Primate Cognition. Oxford: Oxford University Press, 1997.

Tomasello, Michael. A Natural History of Human Thinking. Cambridge, MA: Harvard University Press, 2014. 
Wallace, Bruce. „The Estimation of Adaptive Values of Experimental Populations.“ Evolution 6, no. 3 (1952): 333-41. https://doi.org/10.2307/2405418.

Warneken, Felix, and Michael Tomasello. „The Roots of Human Altruism.“ British Journal of Psychology 100, no. 3 (2009): 455-71.

https://doi.org/10.1348/000712608X379061.

Wertheimer, Max. Productive Thinking. Westport, CT: Greenwood Press, 1978.

Whiten, Andrew, Nicola McGuigan, Sarah Marshall-Pescini, and Lydia M. Hopper. „Emulation, Imitation, Over-Imitation and the Scope of Culture for Child and Chimpanzee." Philosophical Transactions of the Royal Society B: Biological Sciences 364, no. 1528 (2009): 2417-28. https://doi.org/10.1098/rstb.2009.0069. 